\title{
Association of Tumor Necrosis Factor Alpha -238G/A and -308G/A Promotor Polymorphisms with Clearance of Hepatitis B Virus Infection in Turkish Population
}

\author{
Ahmet Çağkan İnkaya ${ }^{1, *}$, [MD] \\ ORCID: 0000-0001-7943-8715 \\ Emel Türk Arıbaş ${ }^{2}$, [MD] \\ ORCID: 0000-0002-4551-413, \\ İbrahim Erayman ${ }^{2}$, [MD] \\ ORCID: 0000-0002-7941-2710 \\ Bahar Kandemir ${ }^{2}$, [MD] \\ ORCID: 0000-0002-9815-8767 \\ Hasan Acar $^{3}$, [PhD] \\ ORCID: 0000-0003-1888-2657 \\ Mehmet Bitirgen ${ }^{2}$, [MD] \\ ORCID: 0000-0002-3105-8665 \\ 1 Hacettepe University School of Medicine \\ Department of Infectious Diseases Sıhhıye, Ankara, \\ Turkey \\ 2 Necmettin Erbakan University Meram Medical \\ Faculty Department of Clinical Bacteriology and \\ Infectious Diseases, 42080, Meram, Konya, Turkey \\ 3 Necmettin Erbakan University Medical Faculty \\ Department of Molecular Biology and Genetics, \\ Konya, Turkey \\ * Corresponding Author: Ahmet Çağkan İnkaya, \\ Hacettepe University School of Medicine \\ Department of Infectious Diseases \\ Sıhhıye, 06100, Ankara, Turkey \\ e-mail: inkaya@hacettepe.edu.tr, \\ DOI:10.32552/2019.ActaMedica.341
}

ee) ABSTRACT Ceer

Objectives: Acute viral hepatitis B may lead to chronic hepatitis in $6 \%$ of adult population. We compared the frequency of Tumor necrosis factor alpha promotor polymorphisms in chronic hepatitis B patients and people with natural immunity against hepatitis $B$.

Materials and Methods: Chronic hepatitis B patients and age matched control cases with natural immunity to hepatitis $B$ virus were recruited 1:1 in this study. Tumor necrosis factor alpha -238G/A and -308G/A polymorphisms were studied with PCR-RFLP. X2 test was performed in statistical analysis.

Results: A total of 101 volunteers enrolled in two study groups. Thirty-eight men and 12 women constituted the chronic hepatitis B patient group and 40 men and 11 women recruited in natural immunity group. Frequency of $-238 \mathrm{G}$ allele was $87.5 \%$ and $97 \%$ in chronic hepatitis B and natural immunity groups, respectively. Frequency of $-308 \mathrm{G}$ allel was $93 \%$ and $92.1 \%$ in chronic hepatitis B and natural immunity groups, respectively. Frequencies of polymorphisms at positions -238 and -308 in the promotor of tumor necrosis factor alpha gene were not different between chronic hepatitis $B$ and natural immunity groups.

Discussion: Tumor necrosis factor alpha promoter polymorphisms at -238 and -308 positions do not effect the outcome hepatitis B infection in Turkish population. Clearance of hepatitis $B$ virus infection is multifactorial. Thus, further studies needed to identify genetic predisposition to chronic hepatitis B infection.

Key Words: Hepatitis B Virus, tumor necrosis factor alpha promoter polymorphism, genetic predisposition to chronic hepatitis B infection.

Received: 01 January 2019, Accepted: 11 Mach 2019 Published on line: 30 March 2019

\section{INTRODUCTION}

Hepatitis B virus (HBV) is estimated to have infected more than 2 billion people worldwide, of whom, 400 million are chronically infected today and are at an increased risk of liver-related sequelae, including chronic hepatitis B (CHB), cirrhosis, fulminant liver failure, liver transplantation, hepatocellular carcinoma (HCC) and death $[1,2]$.

Outcome of HBV infection is affected by viral and host factors. HBx protein, HBeAg and HBV genotypes are the leading viral factors affecting virus clearance [3, 4]. Age is the most pronounced host factor associated with chronic infection. Infants and children tend to develop CHB after acute HBV infection unlike adults. HBV infection during early infancy results CHB in $90 \%$ patients whereas infection during adulthood leads to chronic infection in less than $5 \%$ of patients [5]. Control of HBV infection requires orchestration of innate and adaptive immune systems.

Although immunological data are not available about early intrahepatic events in human infection, data from the animal models of acute HBV infection supports the concept that clearance of HBV DNA mediated antiviral cytokines produced by cells of the innate and adaptive immune response $[6,7]$. In particular, interferon-gamma (IFN- $\gamma$ ), tumor necrosis factor alpha (TNF-a), and Interferon alpha/beta $($ IFN- $\alpha / \beta)$ are believed to trigger several pathways 
leading to inhibition of viral replication without direct destruction of infected cells [3].

TNFa, a small protein of $17 \mathrm{kDa}$ with immunological, inflammatory and homeostatic activities, after binding its receptor, interferes with viral replication mechanisms and causes viral clearance [8]. High levels of TNFa and its receptor found in infiltrating mononuclear cells and hepatocytes of chronic hepatitis B patients [9]. TNFa kills HBx sensitized cells via apoptosis [10] and inhibits HBV core promoter's transcriptional activity in-vitro [11]. TNFa is capable of degrading HBV mRNA [12]. Reactivation of HBV infection occurs in patients receiving anti-TNFa treatment [13]. These findings suggest that TNFa activity is crucial to control HBV infection and viral replication.

Levels of TNF subjected to transcriptional, translational and posttranslational control [8]. TNF gene mapped to the class III region of MHC between HLA-B and DR loci. Several single nucleotide polymorphisms, at TNF promoter region, effecting TNF transcription levels were previously demonstrated [14]. An A allel at the $-308^{\text {th }}$ base of the promoter region results in higher serum TNFa levels compared to $\mathrm{G}$ allele [15]. Similarly, peripheral blood mononuclear cells of liver recipients with -308AA allel, when challenged with Con- $A$, produces TNFa thrice the patients with GG allele [16].

TNFa promoter polymorphisms shown to be involved in pathogenesis of several diseases [17]. Conflicting results were present between studies investigating HBV clearance. The aim of the present study was to determine whether certain TNF promotor polymorphisms affect outcome of HBV infection in Turkish population.

\section{MATERIALS and METHOD}

This study carried out at Selçuk University, Meram Medical Faculty Department of Infectious Diseases and Clinical Bacteriology. Study protocol reviewed and approved by ethical committee of Selçuk University Meram Medical Faculty (Decision: 10.02.2006-2006/045).

\section{Patients}

Fifty CHB patients and 51 age-matched controls with natural immunity (NI) against HBV were recruited in this study. All volunteers provided informed consent. All volunteers enrolled in this trial were coming from central Anatolia. Diagnosis of $\mathrm{CHB}$ based on positive HBsAg over 6 months and elevated blood alanine aminotransferase and aspartate aminotransferase levels. All CHB patients were undergone liver biopsy to determine the liver injury. Liver pathology classified according to modified Knodells' score. Patients with hepatitis C, hepatitis D and HIV co-infection were excluded. Patients consuming alcohol $40 \mathrm{~g} /$ day, patients with cirrhosis and autoimmune hepatitis were also excluded. HBV DNA was measured with real time PCR. Routine follow-ups of patients carried-out at outpatient clinics of Infectious

\section{Diseases}

$\mathrm{NI}$ group consisted of volunteers who spontaneously cleared the HBV infection without any intervention. $\mathrm{NI}$ determined as negative $\mathrm{HBsAg}$, positive antiHBs and antiHBctotal or antiHBe antibodies. All of the NI group were negative for hepatitis $C$ and human immunodeficiency virus antibodies.

\section{Study Procedures}

Two $\mathrm{ml}$ venous blood drawn from all recruited subjects and stored at $4^{\circ} \mathrm{C}$ until DNA isolation. Genomic DNA was isolated from peripheral blood leucocytes using standard phenol-chloroform methods. Isolated DNA kept at $-80^{\circ} \mathrm{C}$. Gene fragments containing the polymorphic sites were amplified by PCR. PCR was performed in a $20-\mu \mathrm{L}$ reaction mixture containing $0.4 \mu \mathrm{L}$ DNA Taq polymerase (Fermentas, England), $50 \mathrm{ng}$ genomic DNA, $20 \mu \mathrm{L}$ $10 \times$ buffer, and $1.5 \mathrm{mmol} / \mathrm{L} \mathrm{MgCl} 2,1.2 \mu \mathrm{L}$ primers and $10 \mathrm{pmol} / \mathrm{L}$ dNTPs. The PCR cycles were as follows: $94^{\circ} \mathrm{C}$ for $3 \mathrm{~min}, 30$ cycles of denaturing at 94 ${ }^{\circ} \mathrm{C}$ for 15 seconds, annealing at $57^{\circ} \mathrm{C}$ for 15 seconds, extension at $72{ }^{\circ} \mathrm{C}$ for 15 seconds, and a single final extension at $72{ }^{\circ} \mathrm{C}$ for 3minutes in an Applied Biosystems GeneAmp PCR System model 2700 thermocycler. After amplification, products were identified under ultraviolet light after electrophoresis in $3 \%$ agarose gel stained by ethidium bromide (EB). Then PCR products were digested by allele-specific restriction enzymes (Ncol, Fermentas, England) (Mspl Promega, USA) overnight at $37^{\circ} \mathrm{C}$. Cleaved DNA fragments then identified by ultraviolet light after electrophoresis in 3\% agarose gel stained by EB. pBR322 DNA/BsuRI (Fermentas, England) DNA ladder was used during analysis (Figure1-2). 
Figure 1: PCR-RFLP for TNFa -238 genotype. M, DNA marker, lane 1 PCR product before digestion (152bp), lane 2: genotype: AA (152bp), lanes 3,7,10,11 genotype GA (152+132+20bp), lanes 4,5,6,8,9,12,13 genotype GG (132+20bp).

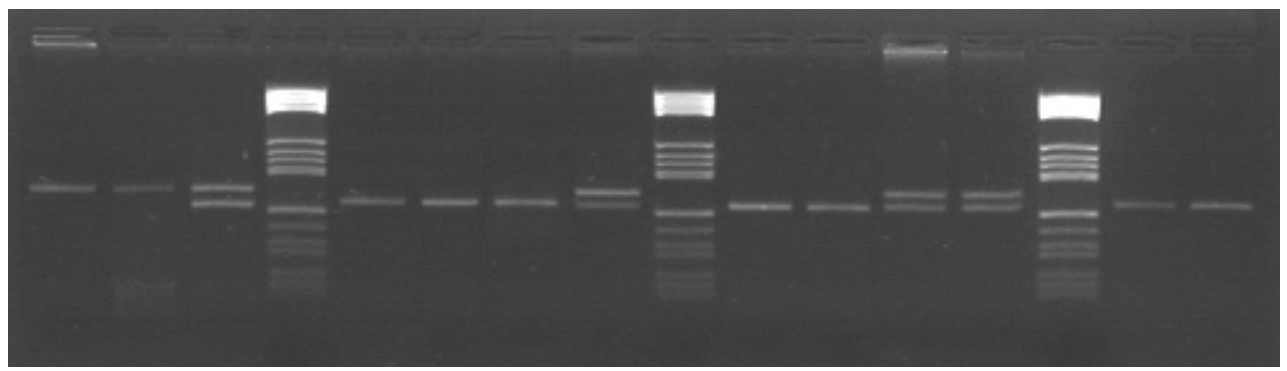

Figure 2: PCR-RFLP for TNFa -308 genotype. M, DNA marker, lane 1 AA allel (107bp), lane 2,4,6,7,8,9,10: genotype: GG (87+20bp), lanes 3,5 genotype GA (107+87+20bp), lanes 4,5,6,8,9,12,13 genotype GG (132+20bp).

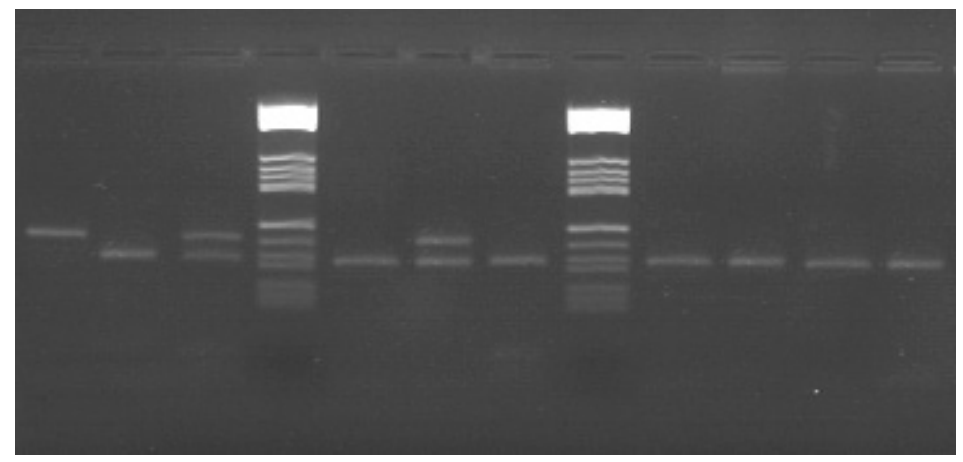

\section{Statistical Analysis}

Data evaluated by $x 2$ test using SPSS 10.0 pro- DISCUSSION gramme with $\mathrm{p} \leq 0.05$ as statistical significance.

\section{RESULTS}

\section{Subject Characteristics}

CHB group consisted of 38 men and 12 women. $\mathrm{NI}$ groups consisted of 40 men 11 women. Patient characteristics summarized in table 2 . Mean age and gender of groups were similar $(p=0,217)$.

\section{Genotype Distributions and Allele Frequencies}

Genotypic frequencies of the two groups shown in table 3. We found -238 GG genotype in $42(84 \%)$ and $48(94 \%)$ of CHB and NI group, respectively. GA genotype was present in $7(14 \%)$ and $3(5.8 \%)$ of $\mathrm{CHB}$ and $\mathrm{NI}$ groups, respectively. AA genotype found in one patient from CHB group. Frequency of -238G allele was higher in NI group but did not reach statistical significance. $-308 \mathrm{G}$ allele was present in $93 \%$ and $92.1 \%$ of $\mathrm{CHB}$ and NI groups, respectively. Frequency

of -238GA and -308GA genotypes did not differ between $\mathrm{CHB}$ and $\mathrm{NI}$ groups.

HBV continues to be public health challenge despite ongoing vaccination programs. HBV is a major cause of morbidity and mortality in high endemicity areas [1, 2]. Outcome of HBV infection has effected by viral and host factors. Among host factors age, is the most prominent factor leading chronic infection. Despite an outstanding interest in the field host factors that are responsible of viral persistence, remain obscure.

The prominent role played by TNFa in inflammation and its relevance to infectious diseases has led to great interest in both the regulation of the TNFa gene, and the possibility that variants of the gene or deregulation of its production may be associated with pathology [17]. The level of TNF production in healthy individuals shows wide and stable variation, with high and low producer phenotypes present in the population, indicating a substantial genetic contribution to TNF regulation [15]. The gene of TNFa is located in the HLA Class III region in the short arm of sixth chromosome. The first $200 \mathrm{bp}$ of 
the promoter are highly conserved across a range of species, with the murine, bovine and porcine promoters showing approximately $80 \%$ homology with the human promoter, while further upstream there is far less conservation between species. Most of the transcription factors capable of binding and regulating the TNFa promoter shown to bind the proximal $200 \mathrm{bp}$ of the promoter [17]. A putative regulatory box (Y-Box) of the TNFa promoter including a SNP at position -238 was described [8]. This putative regulatory box is strongly conserved among the species and believed to contribute the optimal promoter activity [19].

In this study, we evaluated the role of two SNPs in TNFa promoter in clearance of HBV infection. We found that $\mathrm{G}$ allel frequency at $-238^{\text {th }}$ position of the promoter in $87.5 \%$ and $97 \%$ of $\mathrm{CHB}$ and $\mathrm{NI}$ groups, respectively. Difference between groups was statistically insignificant. We also found that $93 \%$ of CHB group and $92.1 \%$ of $\mathrm{NI}$ group had $\mathrm{G}$ allel at position -308 of TNFa promoter.

Höhler, found that -238GG genotype was more common in spontaneously recovered subjects than CHB patients [19]. Miyazoe could not demonstrate a relation between - 238 genotype and viral clearance [20]. Several investigators from China demonstrated a correlation between -238 GG genotype and CHB infection [21-24]. Niro reported that -238 genotype did not affect history of HBV infection [25]. A large study from Korea could not demonstrate a correlation between -238 genotype and viral clearance [26]. In our study, we could not demonstrate a relation between -238 genotype and viral clearance. This could be explained with ethnical differences between populations. Vertical transmission of HBV infection is common in our society like Japanese [27]. Age of transmission could affect the clearance of HBV rather than the -238 allele in Turkish population. It was previously, shown that, an A allel at the $-308^{\text {th }}$ base of the promoter region of the TNFa gene results in higher serum TNFa levels compared to $G$ allele [15]. Similarly, peripheral blood mononuclear cells of liver recipients with -308AA allele, when challenged with Con-A, produces TNFa thrice the patients with GG allele [16]. In order to determine a role for $-308 \mathrm{G} / \mathrm{A}$ polymorphisms in chronic hepatitis pathogenesis, some studies were performed and revealed contradictory results. Höhler and Niro found no correlation between -308G/A polymorphisms and chronic hepatic $B$ outcome $[19,25]$. Kim, found that $-308 \mathrm{~A}$ allel was strongly associated with clearance of hepatitis B infection [26]. Miyazoe could not demonstrate a relation between -308 genotype and hepatitis disease progression [20]. In our study, we could not demonstrate an association between TNF -308 promoter and hepatitis virus clearance. Our data is inconsistent with Höhler's and Miyazoe's results. Ethical differences between study groups and modes of transmission might influence the contradictory results.

Wang could not demonstrate a relation between -238 and -308 genotype and response to HBV vaccination [29]. Age, immune-status of the case and HLA DRB1*07 carriage rather than TNF promoter genotype affect the vaccine response in Wang's cohort. Besides, as TNF loci lie very close to MHC locus, linkage disequilibrium between TNF promoter and MHC loci may exist. Some studies found that TNF308A allel was in strong linkage disequilibrium with HLA-DRB1*13 which had been associated with HBV clearance previously [28]. Exact mechanism that is responsible for the association between $\mathrm{MHC}$ genotype and disease outcome is obscure.

Kim found that SNP's at position -308 and -863 could affect the outcome individually [26]. However, Kim demonstrated that some TNF haplotypes (-1031T; -863C; -857C; -308G; -238G; -163G and -1031C; -863A; -857C; -308G; -238G; -163G) were significantly associated with HBV clearance, suggesting combination of SNP's rather than a single SNP may affect the outcome.

Former studies reported from Turkey, demonstrated that -238G and -308G allel was present in 73.1$\%$ and $68.8-95.2 \%$ of control population respectively [30,31]. Our data is consistent with the former Turkish reports.

Data on TNF alpha promoter polymorphisms and clearance of HBV infection is still incomplete and conflicting. Our study has some limitations. Size of the study group was limited which may lead to underestimation of our results. However, Sghaier [32] showed 308GG allele was protective from HBV infection and -308A allele was related to chronic infection with a similar sample size. Ethnic differences might contribute to conflicting results from different studies. Immune modulation for the treatment of HBV infection is coming-of-age. Understanding the natural mechanisms of viral control may ease our way to define new therapeutic targets [33].

As a result, we could not demonstrate a relation between HBV clearance and TNF promoter -238 and -308 polymorphisms. In our population, age and mode of transmission might be effecting the HBV clearance rather than TNF promoter genotype. 
Linkage disequilibrium between TNF promoter and MHC loci may also be contributing to HBV clearance in Turkish population.

\section{CONFLICT OF INTEREST STATEMENT}

Authors declare that they have no conflict of interest regarding this manuscript.

Table 1. Outline of TNFa promoter genotyping

\begin{tabular}{|l|c|c|c|c|}
\hline Loci & Primer sequences $\left(5^{\prime}\right.$ to $\left.3^{\prime}\right)$ & $\begin{array}{c}\text { PCR } \\
\text { Product }\end{array}$ & $\begin{array}{c}\text { Restriction } \\
\text { enzyme }\end{array}$ & Genotype \\
\hline- & F:AGAAGACCCCCCTCG GAAC & $152 \mathrm{bp}$ & Mspl & GG:132+20bp \\
\hline 238 & R:ATCTGGAGGAAGCGG TAGTG & & & GA:152+132+20bp \\
\hline & & & & AA:152bp \\
\hline- & F:AGGCAATAGGTTTTGAGGGCCAT & $107 \mathrm{bp}$ & Ncol & GG:87+20bp \\
\hline 308 & R:TCCTCCCTGCTCCGATTCCG & & & GA:107+87+20bp \\
\hline & & & & AA:107bp \\
\hline
\end{tabular}

Table 2. Characteristics of study population

\begin{tabular}{|l|c|c|c|}
\hline & & CHB group & NI group \\
\hline Sex & men & 38 & 40 \\
\hline & women & 12 & 11 \\
\hline Age & & & $39.4 \pm 10.17$ \\
\hline mean \pm STD & & $36.7 \pm 11.8$ & \\
\hline
\end{tabular}

Table 3. Genotype distribution and allelic frequencies of study population

\begin{tabular}{|l|c|c|c|c|}
\hline Locus & Genotype & CHB group & NI group & P-value \\
\hline-238 & GG & 42 & 48 & ns \\
\hline & GA & 7 & 3 & \\
\hline & AA & 1 & - & \\
\hline & G & $87.5 \%$ & $97 \%$ & \\
\hline-308 & A & $12.5 \%$ & $3 \%$ & ns \\
\hline & GG & 43 & 43 & \\
\hline & GA & 7 & 8 & \\
\hline & AA & - & - & \\
\hline & G & $93 \%$ & $92.1 \%$ & \\
\hline
\end{tabular}


[1] Lavanchy D. Hepatitis B virus epidemiology, disease burden, treatment, and current and emerging prevention and control measures. J Viral Hepat 2004; 11: 97-107.

[2] World Health Organization Hepatitis B Fact Sheet No. 204 (Revised October 2000) https://www.who.int/en/news-room/ fact-sheets/detail/hepatitis-a (accessed in July 2018).

[3] Visvanathan K, Lewin SR Immunopathogenesis: Role of Innate and Adaptive Immune Reponses, Semin Liver Dis 2006; 26: 104-15.

[4] Thursz MR, Thomas HC. Pathogenesis of chronic hepatitis B. In: Thomas HC, Lemon S, Zuckermann A (Eds). Viral Hepatitis. Massachusetts; Blackwell Publishing Ltd, 2005; 308-22.

[5] De Franchis R, Hadengue A, Lau G, et al. EASL International Consensus Conference on Hepatitis B. 13-14 September, 2002 Geneva, Switzerland. Consensus statement (long version). J Hepatol 2003; 39(suppl 1): S3-25.

[6] Murray JM, Wieland SF, Purcell RH et al. Dynamics of hepatitis $B$ virus clearance in chimpanzees. Proc Natl Acad Sci USA 2005; 102: $17780-85$.

[7] Guidotti LG, Rochford R, Chung J et al. Viral clearance without destruction of infected cells during acute $\mathrm{HBV}$ infection. Science 1999; 284: 825-29.

[8] Herbein G, O'Brien WA. Tumor Necrosis Factor (TNF)- $a$ and TNF Receptors in Viral Pathogenesis, PSEBM 2000; 223: 241-57.

[9] Fang JW, Shen WW, Meager A, et al. Activation of the tumor necrosis factor-a system in the liver in chronic hepatitis $B$ virus infection. Am J Gastroenterol 1996; 91:748-53.

[10] Su F, Schneider RJ. Hepatitis B virus $x$ protein sensitizes cells to apoptotic killing by tumor necrosis factor-a. Proc Natl Acad Sci USA 1997; 94: 8744-49.

[11] Romero R, Lavine JE. Cytokine inhibiton of hepatitis B core promotor. Hepatology 1996; 23: 17-23.

[12] Tsui L V, Guidotti L G, Ishikawa T, et al. Posttranscriptional clearance of hepatitis B virus RNA by cytotoxic T lymphocyte-activated hepatocytes. Proc Natl Acad Sci USA 1995; 92: 12398-402.

[13] Esteve M, Saro C, Gonzalez-Huix F, et al. Chronic hepatitis B reactivation following infliximab therapy in Crohn's disease patients:need for primary prophylaxis. Gut 2004; 53: 1363-65.

[14] D'Alfonso S, Richiardi PM. A polymorphic variation in a putative regulation box of the TNFA promoter region. Immunogenetics 1994; 39: 150-54.

[15] Louis E, Franchimont D, Piron A, et al. Tumour necrosis factor (TNF) gene polymorphism influences TNF-alpha production in lipopolysaccharide (LPS)-stimulated whole blood cell culture in healthy humans. Clin Exp Immunol 1998; 113: 401-06.

[16] Fernandes $H$, Koneru B, Fernandes $N$ et al. Investigation of promoter polymorphisms in the tumor necrosis factor-alpha and interleukin-10 genes in liver transplant patients. Transplantation 2002; 73: 1886-91.

[17] Bayley JP, Ottenhoff THM and Verweij CJ. Is there a future for TNF promoter polymorphisms? Genes and Immunity 2004; 5:315-29.

[18] Louis E, Franchimont D, Piron A, et al. Tumour necrosis factor (TNF) gene polymorphism influences TNF-alpha production in lipopolysaccharide (LPS)-stimulated whole blood cell culture in healthy humans. Clin Exp Immunol 1998; 113: 401-406.

[19] Höhler T, Kruger A, Gerken G, Shneider PP, et al. A tumour necrosis factor alpha (TNFa) promoter polymorphism is associated with chronic hepatitis B infection. Clin Exp Immunol 1998; 111: 579-82.

[20] Miyazoe S, Hamasaki K, Nakata K, et al. Influence of Interleukin 10 gene promotor polimorphisms on disease progression in patients chronically infected with Hepatitis B virus. The American Journal of Gastroenterology 2002; 97: 2086-92.

[21] Lu LP, Li XW, Liu Y, et al. Association of $-238 \mathrm{G} / \mathrm{A}$ polimorphism of tumour necrosis factor alpha gene promoter region with outcomes of hepatitis B virus infection in Chinese Han population. World J Gastroenterol 2004; 10: 1810-14.

[22] Li HQ, Li Z, Liu Y, et al. Association of polymorphism of tumour necrosis factor alpha gene promoter region with outcome of hepatitis B virus infection. World J Gastroenterology 2005; 11: 5213-17.

[23] Du T, Guo XH, Zhu XL et al. Association of TNF-alpha promoter polymorphisms with the outcomes of hepatitis B virus infection in Chinese Han population. Journal of Viral Hepatitis 2006; 13: 618-24.

[24] Li Chen, Zhi Xin C, Li-Juan Zm, et al. The association between cytokine polimorphisms ant the outcomes of chronic HBV infection. Hepatology Research 2006; 36: 158-66.

[25] Niro GA, Fontana R, Gioffreda D, et al. Tumour necrosis factor gene polymorphisms and clearance or progression of hepatitis $B$ virus infection. Liver International 2005; 25: 1175-81.

[26] Kim YJ, Lee HS, Yoon JH, et al. Association of the TNF-a promoter polymorphisms with the clearance of hepatitis $B$ virus infection Human Molecular Genetics 2003; 12(19): 2541-46.

[27] Mıstık R. Türkiye'de viral hepatit epidemiyolojisi yayınların irdelenmesi. In: Tabak F, Balıki, Tekeli E (eds). Viral Hepatit 2007. Viral Hepatitle Savaşım Derneği, İstanbul, Turkey: Ohan Publications, 2006, 10-50.

[28] Höhler T, Geeken G, Notghi A, et al. HLA-DRB1*1301 and 1302 protect against chronic hepatitis B. J Hepatol 1997; 26: 503-07.

[29] [29] Wang C, Tang J, Song W, et al. HLA and cytokine gene polymorphisms are independently associated with responses to hepatitis B vaccination. Hepatology 2004; 39: 978 -88.

[30] [30] Ozen S, Alikasifoglu M, Bakkaloglu A, et al. Tumor necrosis factor a G囚A -238 and G囚A -308 polymorphisms in juvenile idiopathic arthritis. Rheumatology 2002; 41: 223-27.

[31] Karahan ZC, Deda G, Sipahi T, et al. TNF-A -308G/A and IL-6 $-174 \mathrm{G} / \mathrm{C}$ polymorphisms in the Turkish pediatric stroke patients. Thrombosis Research 2005; 115; 393-98.

[32] Sghaier I, Zidi S, Mouelhi L, et al. The relationship between TNF alpha gene polymorphisms (- 238/- 308), TNF RII VNTR (p75) and outcomes of hepatitis B virus infection in Tunisian population. Gene 2015; 568: 140-45.

[33] Valaydon Z, Pellegrini M, Thompson A, et al. The role of tumour necrosis factor in hepatitis B infection: Jekyll and Hyde. Clinical \& Translational Immunology 2016; 5(12): e115. 